\title{
Türkçe Sözlüklere Göre “Salgın” Kavram Alanı
}

\author{
Betül B. Oğuz
}

Özet

Herhangi bir kelimenin bir dildeki seyri sadece dil bilgisel olgulara bağl1 değildir. Kültür, din, zaman, ekonomi gibi birçok etken kelimelerin kullanımında ve onların dil bilgisel veya semantik değişimlerinde etkilidir. Bireyleri toplumsal olarak etkileyen şeylerden birisi de hastalıklardır. Özellikle bulaşıcı hastalıklar söz konusu olduğunda, yalnızca o toplumdaki bireylerin sağlı̆̆ı söz konusu olmamaktadır. Toplumdaki bireylerin sağlığının yanı sıra hastalığın yayılmasında ve sağaltılmasında söz konusu hastalığa ilişkin söz varlığı da toplumda ortaya çıkmaktadır. Dolayısıyla tarihsel süreçte değişen hastalıklar aynı zamanda değişen kelime ve anlamları işaret etmektedir. Bu çalışma kapsamında tüm bulaşıcı hastalıkları kapsayan bir kelime olarak salgın kavramı ele alınmıştır. Güncel Türkçe Sözlüklerde salgın sözcügüyle birlikte kullanılan, epidemi, pandemi, ölet, kıran ve müstevli kelimeleri de yukarıda söz edilen toplumsal değişimleri göz önüne seren farklı sözcüklerdir. Bu kelimelerin farklılıkları kapsadıkları bulaşıcı hastalıkların farklılığını da göstermektedir. Çalışmada salgın kavramının toplumdaki değişimi Türkçe sözlükler aracığı ile tespit edilmeye çalışılmıştır.
Anahtar Kelimeler

Kavram Alanı

Çağrışım Alanı

Salgin

Türkçe Sözlük

Makale Hakkında

Geliş Tarihi: 05.02.2021

Kabul Tarihi: 21.06.2021

Doi: $10.18026 /$ cbayarsos. 874811

\section{Concept Map of "Salgin" According to Turkish Dictionaries}

\begin{abstract}
The trajectory of a word in a language does not only depend on linguistic phenomena. Various factors such as culture, religion, time, and economy have an effect on the use and linguistic or semantic changes of words. Diseases affect individuals socially. Especially with contagious diseases, it is not only the individual's health that is at risk. In addition to an individual's health, vocabulary related to this disease comes into play when it spreads or is cured. Therefore, evolving diseases throughout history also point at evolving words and meanings. In this study, "Salgin" meaning epidemic was examined as a word that covers all contagious diseases. Used alongside "salgin," words in Contemporary Turkish Dictionaries such as epidemi, pandemi, olet, kiran and mustevli all reveal the aforementioned social changes. Differences in these words also indicate differences in contagious diseases they refer to. This study tries to determine the social change related to the word "salgin" by tracing it in Turkish Dictionaries beginning with their first editions.
\end{abstract}

Keywords

Connotations Map

Concept Map

Pandemic

Turkish Dictionaries

About Article

Received: 05.02.2021

Accepted: 21.06 .2021

Doi: 10.18026/cbayarsos.874811

a İletişim yazarı: betul.oguz@cbu.edu.tr

b Dr. Öğretim Üyesi, Manisa Celal Bayar Üniversitesi, Fen-Edebiyat Fakültesi, Türk Dili ve Edebiyatı Bölümü, ORCID: 0000-0002-6743-6293 


\section{Giriş}

Bir dilin söz varlığının görülebileceği en temel kaynaklardan birisi sözlüklerdir. Sözlüklerde olan kelimelerin söz konusu dilde yaşamış olduğu ve/veya yaşadığ 1 bilinmektedir. Elbette (özellikle günümüzde) dile giren yeni kelimelerin toplumda yayılması, kelimelerin kullanımı o dilin sözlüklerini dikkate almadan gerçekleşir. Başka bir deyişle sözlüklerden dilin hızına yetişmesini beklemek doğru değildir. Yazıldığı her dilde sıklıkla ve öncelikle kullanılan sözlüklerin başında Genel sözlükler gelmektedir. "Genel sözlüklerle ilgili çoğu tanımda ve açıklamada öne çıkan hususlar, bu sözlük türünün genel dili yansıtmak amacıyla ortaya konulan bir tür olması ve genel dil unsurlarını içermesidir" (Bozkurt, 2016, s. 9). Genel dil unsurları ise oldukça geniş bir sözvarlığını içermektedir. Ölçünlü bir dildeki tüm kalıp sözleri, argo, terim ve başka sözcük türlerini genel dilin söz varlığına dahil etmek mümkündür.

Sözlükler genel olmalarının yanında farklı temalarla, farklı okur kitleleri için ve farklı biçimlerde de oluşturulabilmektedir. Sözlüklerin sınıflandırılmasındaki ölçütleri, "sözlüğün diline, sözlüğün kapsamına, sözlüğün boyutuna, sözlüğün ortamına, sözlüğün düzenine" (Bekdaş, 2017, s. 55) göre sıralamak mümkündür. Bu ölçütler etrafında ayrı temalarla ve farklı biçimlerle sözlükler oluşturulabilir. Etimolojik sözlükler, kavram sözlükleri, resimli sözlükler vd. ayrı ayrı ölçütlerle oluşturulmuş sözlüklerdir.

Türkiye Türkçesine gelindiğinde ise kullanılacak sözlüklerin başında Cumhuriyetin kurulmasından sonra şimdiki adıyla Türk Dil Kurumu'nun 1945 yılında ilk baskısı ile yayınladığ1 sözlüğü saymak mümkündür. Türk Dil Kurumu 1945'ten 2011 yılına kadar sürekli olarak güncellenen 11 baskı yapmıştır. Kurum, 2011 yılından sonra ise Güncel Türkçe Sözlük'ün gözden geçirilip bir kez daha güncellenmiş yeni sürümünü internet ortamındakullanıcıların erişimine açmıştır. Bu sözlük, https://sozluk.gov.tr/ adresinden herhangi bir üyelik veya giriş istenmeden kullanılabilmektedir. Söz konusu adreste yalnızca Güncel Türkçe Sözlük bulunmamaktadır. Bu sözlügün yanı sıra,

Türkçede Batı Kökenli Kelimeler Sözlüğü

Tarama Sözlüğü

Derleme Sözlüğü

Atasözleri ve Deyimler Sözlüğü

Yabancı Sözlere Karşılıklar Kılavuzu

Türk İşaret Dili Sözlüğü

Kişi Adları Sözlüğü

Karşılaştırmalı Türk Lehçeleri Sözlüğü

Bilim ve Sanat Terimleri Sözlüğü'ne yine aynı adres üzerinden erişmek mümkündür.

Bu çalışma kapsamında başta Türk Dil Kurumu'nun Güncel Türkçe Sözlük'e gelene kadar yayınladığı 11 basılı sözlük ve Güncel Türkçe Sözlük olmak üzere Misalli Büyük Sözlük, Ötüken Türkçe Sözlük ve Okyanus Ansiklopedik Sözlük taranmış ve kaynak olarak kullanılmıştır. 
Çalışmanın ana kavramı olarak salgın kelimesi seçilmiştir. Bu sebeple sözlüklerin taranmasında iki farklı adım izlenmiştir. Bunlardan ilki; salgın anlamında kullanılan diğer madde başı sözcüklerin tespit edilmesidir. Diğeri ise, anlamında salgın bulunan sözcüklerin neler olduğu, nelerin ve/veya hangi hastalıkların salgın olarak görüldügünün bulunmasıdır. $\mathrm{Bu}$ incelemede salgın kelimesinden hareketle gerek kelime anlamlarında gerekse madde içi açıklamalarda başka kelime ve kavramlarla karşılaşılmıştır. Bu da bir kelime ya da kavramın başka kelime ve kavramlarla birlikte oluşturduğu kümeyi göstermektedir. Elbette dildeki kelimeler tek başlarına sözlük madde başı olarak bir anlamı ihtiva ederler. Ancak dilde tek başına anlamı olan bu kelimeleri konuşurken ya da yazarken zihnimizdeki sözlükten seçmemizdeki belirleyici etken bağlamdır. Örneğin bir manavdan alış veriş yaparken zihnimizdeki sözlükten seçilecek söz varlığı bellidir. Bu sebeple böyle bir bağlamda pencere kelimesinin yeri olmayacaktır. Bu yönüyle insan zihnindeki sözlüğün kategorik veya tematik olduğunu söylemek yanlış olmayacaktır. Ferdinand de Saussure bu durumu "seçme ekseni" kavramı ile açıklamaktadır. Her dilin belirli bir sentaksı vardır. Bu sentaks Saussure'ün kavramlaştırmasında "sıralama ekseni" dir(Kıran-Kıran, 2002, s. 121). Dilin konuşurunun bu sıralama ekseninde bir dahlinin bulunması söz konusu değildir. Söz konusu sıralamada hangi öğenin önce ya da sonra geleceği, hangi öğelerin yan yana bulunup bulunamayacağ Dilin konuşuru anlık olarak konuşma dilinde ya da yazar ve şairler edebî eserlerinde bu sıralamayı değiştirebilseler de temel sıralama değişmemektedir.

Türkçe için bu sıralama en basit haliyle; özne + nesne + yüklem şeklindedir. Bu formül çalışma kapsamının dışında kaldığından her ne kadar burada konu edilmeyecekse de evreni anlamada, tanımlamada etkilidir. Bu formülün dışına çıkamayan konuşur, bu yönüyle kısıtlı bir alandadır. Bu kısıtlı dizilimde kendi iradesini ortaya koyabildiği nokta ise yukarıda söz edilen ve Saussure'ün "seçme ekseni" dediği noktadır. İnsan zihnindeki sözlükte ne kadar kelime varsa sıralama ekseninde gerektiği zaman, kişi, durum ve fiille birleştirerek kullanabilmektedir. Yukarıdaki formülden hareket edilecek olursa

Ben bugün elma aldım cümlesinde sıralama eksenini değiştirmeden seçme eksenindeki unsurlar değiştirilerek sınırsız cümlenin kurulabilmesi mümkündür.

Ben bugün elma aldım.

O dün okula gitmiş.

Salgın kavramı ve bu kavram alanında kullanılan diğer sözcükler için de benzer bir durum söz konusudur. Türkçe sözlükte olan onca sözcüğe rağmen salgin kavram alanında olan ölet, epidemi, pandemi, kıran ve müstevli gibi sözcüklerin hangisinin ne zaman hangi durumda ve hangi hastalık bağlamında kullanılacağı seçme ekseni sayesinde mümkündür. Kavram kelimesi ise bu kapsamı ifade etmektedir. Güncel Türkçe Sözlük'te kavram; "1. Bir nesnenin veya düşüncenin zihindeki soyut ve genel tasarımı, mefhum, fehva, konsept, nosyon. 2. Nesnelerin veya olayların ortak özelliklerini kapsayan ve bir ortak ad altında toplayan genel tasarım, mefhum konsept, nosyon" olarak tanımlanmaktadır. Bu yönüyle bir kavram olarak salgın sözcügüüü bağlamdan bağımsız düşünmek mümkün değildir. Salgın kavram alanında birden fazla sözcügü̈n bulunması ilk olarak farklı salgınları ve bunların toplumsal etkilerini akla getirmektedir. Bu yüzden de salgın kavram alanındaki her bir sözcüğün Türkçeye girdiği andan başlayarak kullanım süresi boyunca başka kelimeleri de akla getirmesi söz konusudur. "Bir düşünce, görüntü vb.'nin bir başkasını hatırlatması" ise çağrışım sözcügüunün Güncel Türkçe Sözlük'teki ilk anlamıdır. Çağrışım noktasından bakıldığında salgın kavram 
alanındaki sözcüklerin birbirleriyle örtüşen ve farklılaşan tarafları ise sadece dil bilgisel değil toplumsal olguları da gözler önüne sermektedir.

Konuyla ilgili salgın sözcüğünün İngilizcedeki karşılığı, anlatılmak istenen durum için örnek teşkil etmektedir. Toplumları etkileyen hastalıkların -ki, bu hastalıkların etkisi arttığında salgın olduğu kabul edilmektedir- bulaşıcı olmaları hastalığın yayılma hızını arttıran bir durumdur. Günümüzdeki küresel salgında da sıklıkla atıf yapılan veba da şimdi olduğu gibi geçmişte tüm dünyayı etkisi altına almış bir salgındır. BBC'nin yayınladığı haberlere göre; İngiltere'de 1665-1666 yıllarında yayılan ve "büyük salgın" olarak adlandırılan veba salgınında Londra nüfusunun dörtte birinin öldüğ̈̈ görülmektedir. Bir salgın olan veba, İngilizcede plague sözcügü ile ifade edilmektedir. İngiltere' de olduğu gibi tüm dünyada etkili olan veba salgınından sonra görülen en büyük salgın, hâl-i hazırda yaşadığımız Covid-19 salgınıdır. Toplumsal etkileri olan olayların dil bilgisel ve anlam bilimsel olarak dile geçişinin örneği de veba ve salgın arasındaki ilişkinin İngilizcedeki yansımasıdır. Günümüzde İngilizcede salgın kelimesi için pandemi kelimesi kullanılmaktadır. Pandemi sözcügü tüm Covid-19 süreci boyunca tüm dillerde kullanıma girmiş ve tıpkı Covid-19, Corona virüs kelimeleri gibi ortak bir sözcük haline gelmiştir. İngilizcede pandemi sözcüğü dışında kullanılan ve "salgın" kavram alanında yer alan bir diğer sözcük ise yukarıda veba anlamını taşıdığ1 ifade edilen plague sözcügüdür (Atalay, 1999, s. 2606). Plague sözcüğü sadece bir hastalık adı iken toplumdaki etkisinin kuvveti ve yıkıcılı̆̆ sebebiyle bir kümenin üyesi olması durumunu kümenin kendisine dönüşerek genişletmiştir. Bunun sonucunda, günümüzde İngilizcede Covid-19 salgını için de pandemi kelimesinin yanında plague sözcügü de kullanılmaktadır.

Türkçedeki salgın kavram alanında kullanılan kelimelerin seyrinde de atıfta bulunulan ya da örneklenen çeşitli hastalıkları izlemek ve değişimi görmek mümkündür.

\section{Salgın Kavramı}

Salgın kelimesini 1945 yılında basılan ilk Türkçe Sözlük'ten itibaren bulmak ve takip etmek mümkündür. Bu ilk baskıda salgın sözcüğü; "s. 1. Birden her kese bulaşan. Salgın hastalık. Salgın görenek. 2. i. Bir şeyin, herkese birden bulaşması hali. Moda salgını. Kumar salgını. 3. i. Kamu işleri için her kesten toplanması gereken para veya malc" şeklindedir. Tanımda da görülebileceği gibi kelimenin birinci anlamında; salgının bulaşıcı olması görenek kelimesi ile örneklenmiştir. Salgın kelimesinin anlamında alışkanlık anlamındaki görenek kelimesinin kullanılması sözlüğün diğer on baskısında ve Güncel Türkçe sözlükte bulunmamaktadır. Salgın görenek ya da buna benzer bir örnek, çalışma kapsamında taranan Misalli Büyük Sözlük, Ötüken Türkçe Sözlük ve Okyanus Ansiklopedik Sözlük'te de yer almamaktadır. "Salgın” sözcüğü bir hastalığı belirttiği için kendi anlamında olumsuzluk içerdiğini söylemek yanlış olmayacaktır. Ancak burada salgın görenek örneğini açıklayan bir cümle verilmediği için bir salgın olarak görülen göreneğin ne olduğu bilinmemektedir. Yine kelimenin anlamının karşılıklarında görüleceği üzere salgın kelimesinin hastalıkla ilgilendirilmesi kelimenin birinci anlamında örnek olarak verilse de doğrudan kelime anlamında hastalık ile ilgili bir açıklama yoktur. Bu durum yalnızca Misalli Büyük Sözlük'te farklılık göstermektedir. Söz konusu

\footnotetext{
c Buradaki madde TDK'nın 1945 yılında yayınladığı sözlükten yazımı değiştirilmeden aynen alınmıştır.
} 
sözlükte kelimenin birinci anlamı; "Kolera, tifo vb. kısa zamanda yayılan (bulaşıcı hastalık)" (Ayverdi, 2016, s. 1053) şeklindedir.

Türkçe Sözlük'ün 1945 yılındaki baskısında salgın kelimesinin üçüncü anlamında vergi kelimesinin kullanılması sözcükteki değişimin en net işaretidir. Salgın kelimesinin vergi anlamı her ne kadar 1945 yılında üçüncü ve son anlam olarak verilse de yine Türk Dil Kurumu'nun yayınladığı Tarama Sözlüğü'nde birincil anlam olarak görülmektedir. Tarama Sözlüğü'nde "Salma yoluyla alınan vergi, keyfi vergi" (1995, s. 3265) anlamındaki salgin kelimesinin 14-18. Yüzyıllar arasında bu anlamı ile kullanıldığını görmek mümkündür. Türk dilinde Osmanlı dönemine gelene kadar vergi anlamında salgın yerine yine aynı kökten türemiş olan salıg (Özyetgin, 2007, s. 455) kelimesi "olağanüstü durumlarda istenen vergi" anlaminda kullanılmıştır. Osmanlı dönemine gelindiğinde salıg kelimesi yerini salgın-salgun kelimesine bırakmış ve kelimedeki vergi anlamı da devam etmiştir. Tarama Sözlüğü'nde salgın kelimesine karşılık olarak verilen vergi sözcügü de bu değişimin yansımasıdır. Ötüken Türkçe Sözlük de kelimenin Eski Anadolu Türkçesi dönemindeki kullanımını vermekte ve salgın kelimesinin "vergi toplanmasına halkın verdiği ad" (Çağbayır, 2007, s. 4039) olduğunu belirtmektedir.

Salgın kelimesi, madde başı olmasa da Türkçe Sözlük'e gelmeden önce Lugat-ı Remzi'de bulunmaktadır. Sayılan sözlüklerde verilen anlamlar salgın kelimesinin "vergi" kavram alanından bulaşıcı hastalık, salgın alanına gerçekleşen değişimi göstermektedir. Lugatı-1 Remzi' de "dā'ül-'araḳ-ı cāversį" kelimesinin anlamı: “Tibbiyyeden olup salgın surette icrâ-yı hükm eden sâri bir maraz-1 veba'îye denilir ki daimî olarak terin izdiyâdı ve ciltte gayr-1 sâbit bir kabarcık ile muttasıf ve adem-i iştihâ ve sudâ ve bilhassa dizlerde ve bileklerde veca ârazıyla bed' eder"' (1887, s. 525) şeklindedir.

Tespit edilebildiği kadarıyla, salgın kelimesinin madde başı olarak görüldüğü en erken sözlük Lehçe-i Osmanî’dir. “Salgın: Salar ve salmış manasına. Salgın deli tecennün. Salgın hastalık maraz-1 müstevli salyane tevzi olunmuş vergi, salyan. Salgın köpek. Türkîde salıg ve salgın" (Toparl, 2000, s. 328). Burada ilk kez madde başı olarak görülen salgin sözcügünün ilk anlamı tıpkı 1945'teki Türkçe Sözlük'te olduğu gibi doğrudan hastalık değildir. Kelimenin hastalık anlamı yine örnek üzerinden verilmiştir.

Salgin sözcügü madde başı olarak Lehçe-i Osmanî’den sonra Kâmûs-i Türkî'de izlenebilmektedir. Sözlükte salgın maddesi, “1. Salar, hücum eder, tecavüz ve ve te' addi eden: Salgın köpek. 2. Herkese geçen, müstevli: Salgın hastalık: Kolera ve veba gibi bir memleketi istila eden illet-i sariye: Tevzi olunmuş yıllık vergi, salyane" (2005, s. 1034) şeklinde geçmektedir. Her iki madde arka arkaya verildiğinde birbiriyle ne kadar yakın olduğu görülebilmektedir.

Madde başı olarak salgın sözcügüünde vergi anlamı sözlük sıralamasında geriye giderken sözcükteki bulaşıcı hastalık anlamındaki ilk spesifik örnek 1955 yılında basılan Türkçe Sözlük'ün ikinci baskısında ortaya çıkmaktadır. Kelimenin anlamı 1945 yılı ile birebir aynı olarak verilirken, 1945 'te moda salgını ve kumar salgını örneklerinde değişiklik olmuştur. 1955'teki sözlükte moda salgını ifadesi kalkmış bunun yerine "Tifo salgını" örneği kullanılmıştır.

Tifo 19. yy'dan itibaren ortaya çıan bir bulaşıcı hastalıktır (TUBİTAK, 2020). Erken Cumhuriyet döneminde de Atatürk'ün İsmet İnönü'ye yazdığı bir mektupta önlem alınması gereken konulardan biri olarak tifo salgını da sayılmıştır. Atatürk bu mektubunda tifo, verem 
ve frengiyi "ciddi bir sorun" (Yücel, 2017, s. 72) olarak tanımlamaktadır. Tifonun yeni Cumhuriyette her sene tekrar ettiğini, salgının önünün alınması için bostanların ve içme sularının temizlenmesi faaliyetlerini dönemin basınından takip etmek mümkündür. Salgının seyri hakkında gazetelerde verilen bilgiler ve salgın etrafında dönen tartışmalar günümüzdeki haber ve söylemlerle de örtüşmektedir. Günlük vaka sayıları, alınan karantina önlemleri ve vatandaşa karşı sürekli temizlik konusunda yapılan uyarılarda tifo kelimesi yerine covid-19 kelimesi konulduğunda birebir örtüştüğü görülebilmektedir. Tifo günümüzde de kirli içme suları ve pis yiyecekler ile bulaşı hâlini sürdürmektedir. "Dünyada her yıl 20 milyon civarında tifo vakası ortaya çıkarken, bu vakaların 200 bin kadarı ölümle sonuçlanmaktadır" (Parıldar, 2020, s. 23). Tifo günümüzde bile bu kadar etkili iken Cumhuriyet dönemindeki durumu yukarıda da belirtildiği gibi salgın hâlindedir. Dönemin gazetelerine bakıldığında, örneğin 1931 yılında çıkan haberlerde, bulaşıcı hastalıkların yayılması durumunun salgın kelimesi ile değil müstevli kelimesi ile ifade edildiği görülmektedir. Müstevli kelimesi Güncel Türkçe Sözlük'te; "1. Sıfat, eskimiş Bir yeri istila eden yönetimi altına alan (kimse, devlet, ordu vb.). 2. Sıfat, eskimiş Salgın" şeklinde açıklanmıştır. Görüldüğü gibi müstevli kelimesinin "salgın" anlamı günümüzde tamamen kullanımdan düşmüştür. Müstevli sözcüğünün günümüzde sözlüklerde "sıfat, eskimiş" ifadesiyle yer alması 30'lu yıllarda salgın kelimesi için geçerlidir. Yine gazete haberlerinde salgin zamanlarda, tifo salgın halinde gibi kullanımlarda salgın kelimesinin hastalıkla ilişkilendirilmesi başlamış ancak henüz yaygın bir kavram hâline gelmemiştir.

Burada "salgın" kavramının anlam seyri gerek alfabenin değişmesi gerek Öztürkçeleşme hareketleri ile Türkçenin de seyrini göstermektedir. Ulus devletleşme sürecinde yapılan devrimlerden biri olan Arap alfabesinden Latin alfabesine geçme sürecinde Osmanlıca kelimelere Türkçe karşılıklar teklif edilmiştir. Türkçenin sadeleşmesi ve sonrasında alfabenin yayılmasında, bugünkü adıyla Türk Dil Kurumu kurulmuş ve Türkçe ile ilgili meselelerin ele alınması için kurultaylar düzenlenmiştir. Bu süreçte 1945 yılında ilk Türkçe Sözlük basılmadan önce kullanılan Osmanlıca kelimelere Türkçe karşılıklar bulunması için adeta bir seferberlik başlatılmıştır. Bunların sonunca yine Türk Dil Kurumu tarafından Osmanlıcadan Türkçeye ve Türkçeden Osmanlıcaya karşılıklar kılavuzları yayınlanmıştır. Gazeteler tüm bu zaman zarfında etkili bir rol oynamıştır. Radyo ve gazete yegane haber alma kaynağı olarak yeni kelimelerin yayılmasında ve belirlenmesinde öncülük etmiştir. Müstevli kelimesinin salgın kelimesine dönüşümü de gazetelerde yer verilen Osmanlıcadan Türkçeye Karşılıklar Kılavuzu'nda yer almıştır. Ulus Gazetesi de söz konusu kılavuzu her gün bir parça olmak üzere yayınlamıştır. Gazetenin 27 Nisan 1935 tarihli nüshasında bu kılavuzun 34. sayısı yayınlanmıştır. Alfabetik olarak verilen kılavuzda salgın geçen iki sözcük bulunmaktadır. Bunlardan ilki, müstevli: Salgıncı ve diğeri, müstevli olmak: Salgın etmek'tir. Bu dönüşümün yansıması yani 1945'te Türkçe Sözlükte salgın hastalık örneğinin verilmesine gelene kadar salgın kelimesi 1937 yılında artık günümüzdeki şekli ile kullanılmaya başlanmıştır. Yine tifo hastalığının konu edildiği yaz dönemine denk gelen haberlerde hem haber içeriklerinde hem de haber başlıklarında tifo salgını ifadesi görülmektedir. Örneğin; 30 Haziran 1937 tarihli bir haber: "Tifo Salgınına Karşı Şehirde Yeniden Aşı Merkezleri Açılmalı". Yine Temmuz ayındaki bir haber; "Tifo Salgınına Karşı Mücadele” başlığını taşımaktadır.

Yukarıda sözlüklerin dildeki kelimeleri göstermede dilin değişebilirlik ilkesi sebebiyle zaman zaman topluma göre geriden gelebileceğinden söz edilmişti. Her ne kadar bu çalışmanın kapsamı Türkçe Sözlük ile sınırlandırılmış olsa da dikkat çekici bir edebî örneği sunmak 
gerekmektedir. Gazetelere bile 1930'ların ikinci yarısında giren salgin kelimesi Ömer Seyfettin'in dilinde günümüzdeki kullanımı ile yer almaktadır. Ömer Seyfettin 1919 yılında yazıdı̆̆ı bir gazete yazısında; “Netice: -Sevgili kari’lerim şu İspanyol salgını şehrimizden def oluncaya kadar bol bol sarımsak yiyiniz! Ağzınız kokuyor diye kimse sizi ayıplamayacak! Çünkü keyif için değil, ilaç için yiyeceksiniz..." (Polat, 2016, s. 633) tavsiyesi ile salgın kelimesini kullanmıştır.

Salgın kelimesinin 1955'ten sonra basılan 1959 baskısında verilen anlamları sözcügüun açılamasına dördüncü bir madde eklenmesi dışında kelimesi kelimesine aynıdır. 1959 baskısında eklenen dördüncü yan anlam ise şöyledir: "is. Bir şeyin bir yere girip her yanı kaplaması, istila: Çekirge salgını”. Böylelikle 4 anlamı olan salgın sözcügünün sözlükteki seyri 1983 senesindeki 7. baskıya kadar hiç değişmemiştir. Kelime 1983 yılında beş madde ile anlamlandırılmıştır. 1983'teki açıklamada kelimenin bulaşıcı hastalık ile olan ilgisi birinci maddede açılaması genişletilerek verilmiştir. Salgın 1983'teki Türkçe Sözlük'te şöyledir: “1. Kısa zamanda çevredeki insan, hayvan ya da bitkilerin büyük bir bölümüne bulaşan, müstevli: Salgın hastalık. 2. a. Bir hastalığın ya da başka bir durumun birçok kimselere birden bulaşması: Tifo salgını. Kumar salgını. 3. a. esk. Gereğinde herkesten para ya da mal olarak toplanan geçici vergi. 4. a. Bir şeyin bir yere girip her yanı kaplaması, istila: Çekirge salgını. 5. a. mec. Belli bir eylemin, davranışın, sözün toplumda yaygınlaşması: "Anket ve hatıra defteri modası çok salgındı." -A. Nesin." Görüldügü gibi ilk iki anlam da doğrudan hastalık ile ilgilidir. Ayrıca kelimenin vergi kavramı ile olan ilgisinin tamamen kullanımdan düşmüş olması da üçüncü maddenin başında verilen esk. kısaltması ile açıkça görülmektedir.

Burada dikkat çekici bir husus daha bulunmaktadır. Bir dilde kelimelerin yan anlam kazanması ve anlamlarının çoğalması söz konusu kelimenin kullanım sıklığının yanı sıra uzun zamandan beri kullanıldığının da göstergesidir. Salgın kelimesinde de ilk kez 1983 yılında eklenen beşinci anlamda mecazi ibaresinin bulunması kelimenin kullanıldığı dönemde kabul gördüğünün işaretidir. Burada salgının bulaşıcılığı ve hızla yayılması özellikleri ile analoji kurularak bir metafor üretilmiş ve Aziz Nesin'den alınan örnekte görüldüğü gibi anketler salgın olarak nitelenmiştir. Salgın kelimesinin 1983'te değişen anlamının kalıplaştığını söylemek mümkündür. Günümüzde dahi her ne kadar verilen beş anlamın sıralaması değişmiş olsa da Güncel Türkçe Sözlük'te aynı anlamlar kullanılmaktadır. Burada ayrıca sözlüğe 50'lerde giren tifo salgını örneğinin 2021'de de kalmış olması dikkat çekicidir. Son bir yıldır dünyada görülen Covid-19 salgınının ardından Güncel Türkçe Sözlük'ün de tifo örneğini değiştirmesi şaşırtıcı olmayacaktır.

Türkçe Sözlük'te salgın kelimesinden türetilmiş salgıncl, salgınlaşma ve salgınlaşmak kelimeleri de bulunmaktadır. Bu üç sözcük arasında en eski olanı salgıncı kelimesidir. 1945 yılındaki ilk Türkçe sözlükte salgıncı kelimesi bulunmaktadır. Salgın kelimesinin vergi anlamı ile kullanıldığı ve bu dönüşümün nasıl gerçekleştiği yukarıda verilmeye çalışılmıştı. Salgıncı kelimesinin anlamında "salgın toplıyan (kimse)" açıklaması vardır. Bu açılama 1974 yılına kadar olarak devam etmiştir. Sözcüğün anlamında bir değişiklik olmasa da Türkçe Sözlük'ün 1983 yılındaki baskısında kelimenin artık eskiden kullanıldığ gelindiğinde kelimeye bu anlamın yanı sıra başka bir anlam daha eklenmiştir. 1988' de kelime, "salgın toplayan kimse, salgınlaşmak Salgın durumuna gelmek" hâlini almıştır. Salgıncı kelimesi her ne kadar 2005 yılında basılan Türkçe sözlükte bulunmasa da Güncel Türkçe Sözlük'te “isim, eskimiş Salgın toplayan kimse" şeklinde bulunmaktadır. Yukarıda müstevli kelimesinin 1935 'te salgıncı karşılığı ile teklif edildiği belirtilmişti. Bundan çok daha önce 1930 yılında 
Cumhuriyet gazetesinde tefrika edilen bir metinde salgıncı kelimesi geçmektedir. Bu örnekte dikkat çeken durum salgıncı sözcügünü sadeleştirilmede Türkçe karşıllk olarak defterdar kelimesinin yerine kullanılmış olmasıdır (27.11.1930). Ancak görünen odur ki salgın kelimesinin bulaşıcı hastalıkla ilgisi arttıkça vergi ile olan semantik ilişkisi kopmuş ve salgıncı kullanımdan düşerken defterdar kelimesi dildeki varlığını korumuştur. Salgıncı kelimesi ele alınan diğer sözlüklerden Misalli Büyük Türkçe Sözlükte (2016, s. 1053) ve Ötüken Türkçe Sözlükte (2007, s. 4039) de madde başı olarak yer almaktadır. Her iki sözlükte de salgıncı kelimesinin açılamasında defterdar yerine tahsildar kelimesi tercih edilmiştir.

Salgınlaşma ve salgınlaşmak kelimelerinin ikisi de 1998 yılında basılmış olan 9. baskıda sözlüğe girmişlerdir. Sonrasında günümüze kadar da sözlüklerdeki varlıklarını sürdürmüşlerdir. Salgınlaşma kelimesi; "salgınlaşmak işi veya durumu, salgınlaşmak: salgın durumuna gelmek" şeklindedir. Her iki kelime de aynı anlamda kullanılmakta ve ele alınan ve taranan diğer sözlüklerde ise yer almamaktadır.

"Salgın" kavramına sözlükler üzerinden bakıldığında en dikkat çekici şey kelimenin odağının değişmiş olmasıdır. Salgın sözcüğünün vergi anlamında kullanımında halktan alınan, talep edilen bir şey söz konusu iken hastalık anlamı ile bu durum değişmiştir. Salgının hastalık kavram alanı ile ortaya çıkması bu ilişkiyi tersine çevirmiştir. Kelimenin anlamındaki alıcı verici değişikliği kelimenin algılanışındaki temel noktayı da etkilemiştir.

\section{Müstevli}

Her dil kendi kavram kümeciklerini var ederken, "değişik yollardan, değişik kavramlarla ilişki kurarak oluşturur" (Aksan, 2006, s. 41). Yukarıda salgın kelimesinin anlam değişikliği yaşadığı dönemde aynı kavram alanında müstevli kelimesinin kullanıldığından söz edilmişti. Türkçeye Arapçadan geçen müstevli kelimesi basılı ilk Türkçe sözlükten itibaren izlenebilmektedir. Kelime 1945 yılında; "1. Salgın. 2. Basan, kapliyan, kabanlıyan, basıran" şeklinde tanımlanmıştır. Bu tanımda yer alan ve müstevli kelimesini açıklayan kabanla- ve basırfiilleri günümüzde kullanılmamaktadır. Cumhuriyetle birlikte üretilen ve/veya türetilerek teklif edilen kelimeler tüm dillerde olduğu gibi ya toplum tarafından kabul görmekte ve dolaşıma girmekte ya da tutunamamaktadır. Kabanla- fiili sadece 1945 yılındaki sözlükte yer almış ve "bir yere üşüp orasını kendi erki altına almak, istila etmek" diye açıklanmıştır. Basırfiili ise 1945, 1955, 1959 ve 1966 baskılarında aynı anlam ile verilmiştir. Verilen bu anlam; “1. Zorlamak, cebretmek. 2. Yenilgiye uğratmak"tır. Bu fiil de müstevlinin yıkıcılığını göstermektedir. Yine aynı yıllarda basır- fiili ile birlikte; basırgın-, basırgan-, basırgama, basırganma kelimeleri de bulunmaktadır. Bu sözcüklerin anlamlarındaki “kabus çökmek, üzerine ağırlık basmak" ifadeleri de salgın kelimesinin olumsuzluğunu pekiştirici niteliktedir.

1955'ten 1983 yılına kadar basılan tüm sözlüklerde müstevli kelimesinde her iki fiil de kullanım dışı bırakılmıştır. Bunun yerine; "1. Salgın. 2. Basan, kaplayan” açıklaması tercih edilmiştir. Salgın kelimesine benzer şekilde müstevli kelimesinin de 1983 yılındaki anlamı günümüze kadar sürmüştür: “esk. 1. Bir yeri istila eden, yönetimi altına alan (kimse, devlet, ordu vb): "Hatta bu iktidar sahipleri şahsi menfaatlerini müstevlilerin siyasi emelleriyle tevhit edebilirler." -Atatürk. 2. hek. Salgın". Burada en büyük fark elbette kelimenin 1983'te güncellenen anlamında kendi döneminden değil Atatürk'ten bir örnek verilmiş olmasıdır. Bu durum da kelimenin 80’lerden itibaren kullanımının azaldığını göstermektedir. 
Müstevli kelimesi Güncel Türkçe Sözlük'te de bulunabilmektedir. Kelime iki anlamla verilmiştir ve verilen her iki anlamda da eskimiş ibaresi vardır. Ayrıca Okyanus Ansiklopedik Sözlük'te kelimenin salgın anlamının eskiden kullanıldığı belirtilmiştir (Tuğlacı, 1971, s. 2068)

\section{Kiran}

Müstevli ve salgın kelimesi ile çağdaş olan bir başka kelime ise kıran sözcüğüdür. Kıran kelimesi Türkçeden Osmanlıcaya Cep Kılavuzu'nda müstevli kelimesine karşlık olarak teklif edilmiş bir sözcüktür: "Kıran: Marazı mühliki müstevli" (1935, s. 191). Bu anlamda geçen Osmanlıca ifadeler salgın halindeki öldürücü, helak edici hastalığı işaret etmektedir. Eski Türkçede kırfiilinden türeyen kıran kelimesi Dede Korkut'ta "Canavarları serveri kağan aslan kıran" şeklinde geçmektedir. Burada kelimenin "öldürmek" anlamında kullanıldığ1 görülmektedir. Dede Korkut'un Muharrem Ergin'in neşrettiği nüshasındaki sözlükte kıran kelimesi; "kıran, büyük en büyük, (veya) öldürücü salgın" (2009, s. 181) anlamındadır. Aynı eserde kırgun kelimesi de geçmektedir. Bu kelimenin anlamında da "ölüm salgını" ifadesi kullanılmıştır. Kıran kelimesinin Eski Anadolu Türkçesindeki takibini Tarama Sözlüğü'nden yapmak mümkündür. Tarama Sözlügü̈nde kıran kelimesi “öldürücü hastalık salgını” (1995, s. 2502) şeklindedir.

Sözlükte Tarih-i İbn Kesir'den alınan örnek kelimenin cümle içerisindeki kullanımını da göstermektedir: "Kıran vaki' oldu, kızlıktan ve kırandan çok kişiler öldüler". Bu örnekte kıran kelimesi herhangi bir hastalık ismi geçmeden verilmiştir. Günümüzde de "kıtlıktan insan öldü" biçimi kullanılmaktadır. Kıtlık kelimesinin yokluk, yoksulluk anlamı onu başka bir özel durumla ilişkilendirme ihtiyaç duyurmamaktadır. Dilde söylenmeyenler aslında en çok bilinen ve söylenmesine gerek dahi duyulmayan öğelerdir. Bugün Covid-19 salgını olmamış olsa salginda insanlar öldü cümlesi kuran birisinin hangi salgında? cevabını alması kuvvetle muhtemeldir. Salgında yokluktan farklı olarak yayılacak bir şeye, hastalığa ihtiyaç duyulmaktadır. Ancak daha önce de söylendiği gibi aynı cümle an itibariyle kurulmuş olsa zaten bir salgının içerisinde olunduğu için salgın kelimesinin hangi salgımı ifade ettiği çok açıktır. Hatta kastedilen Covid-19 değilse onun belirtilmesine ihtiyaç duyulmaktadır: Tifo salgınında çok insan öldü gibi. Burada kırandan insan öldü denilmesinde de dönem okurunun soru sormadığı bir durumdan söz edilebilir. Kâmûs-i Türkî' de kıran kelimesi burada söz edilen biçimde bir örnekle verilmiştir: "Koyunkıran: Koyunları itlaf eden salgın hastalık; saçkıran: saçı düşürür illet, sa'üs-sa'leb" (2005, s. 1125). Kıran sözcügünün Türkçe Sözlük'teki seyri ise ilk baskıdan itibaren görülebilmektedir. Kıran kelimesi sözlükte; "1. Kırmak işini yapan. Taş kıran, Odan kıran. 2. i. Bir topluluğun ve özellikle hayvanların büyük bir kısmını yok eden hastalık veya başka sebep. Bu yıl sığırlara kıran girdi” şeklinde tanımlanmıştır. Bu anlam 1974'e kadar tüm sözlüklerde kullanılmıştır. Burada dikkat çeken nokta kıran sözcüğünün özellikle hayvanlar için kullanıldığının altının çizilmesidir. Kıran kelimesindeki "salgın" anlamının hayvanlar ile ilişkilendirilmesi günümüzde de devam etmektedir. 1983 yılında kırfiilinin sıfat fiilli yapısı sözcüğün birinci anlamı olarak verilmiştir ve dolayısıyla salgın anlamı ikinci sıralamaya gerilemiştir. 1988 yılında bu sıralama ve anlamlar değişmezken örnek olarak bir atasözü verilmiştir. Verilen; "kırk yıl kıran olmuş, eceli gelen ölmüş” örneği 2005 yılına kadar devam etmiştir. Aynı örnek Misalli Büyük Türkçe Sözlük'te de yer almaktadır. 1998 yılında bu atasözüne ek olarak Sait Faik Abasıyanık'tan bir örnek daha eklenmiştir. Güncel Türkçe Sözlük'te de atasözü örneği çıkartılmış ve Sait Faik'in örnek cümlesi korunmuştur. 
Kıran kelimesinin bir özelliği ise bu çalışma kapsamında ele alınan salgın kavram alanındaki diğer kelimeler arasında en fazla birleşik yapıya sahip sözcük olmasıdır. Bu anlam değişmeleri, gerçek ve mecaz anlamla kurulan yapılar ilk kez 2005 yılındaki baskıda sıralanmıştır. Kıran kelimesinin 2005 yılındaki anlamı şöyledir: 1. Kırma işini yapan (kimse): Taş kıran işçiler. 2. is. Bir topluluğun ve özellikle hayvanların büyük bir bölümünü yok eden hastalı veya başka sebep, ölet, afet: "Kıranları ve zelzeleleri, feyezanları ve harpleri görmüşlerdir." -S. F. Abasıyanık. kıran girmek 1) kısa bir zaman içinde çok sayıda ölmek: Bu yıl sığırlara kıran girdi. 2) bir şey hiç bulunmaz olmak. kıran kırana, bacakkıran, buzkıran, dalgakıran, dalkıran, evcikkıran, findikkıran, filizkıran, kayışkıran, Kervankıran, kılkıran, malkıran, pirekıran, sabankıran, saçkıran, taşkıran, yelkıran, yıldırımkıran. Tüm bu örnek yapılar günümüzde Güncel Türkçe Sözlük'te de yer almaktadır. Bu noktada şöyle bir fark vardır; burada verilen örnekler "bir şey bulunmaz olmak" anlamının kapsamında verilmiştir. Oysa Güncel Türkçe Sözlük'te kelimeden türetilen ve yukarıda sıralanan birleşik yapılar; "1. Kırma işini yapan (kimse) 2. Bir topluluğun ve özellikle hayvanların büyük bir bölümünü yok eden hastalık veya başka neden, ölet, afet" anlamı altında sıralanmıştır. Bu birleşikler içinde yalnızca "Danakıran otu" örneği 2005 yılındaki listede bulunmamaktadır. Kıran kelimesinin 2005'te verilmiş "bir şey bulunmaz olmak" anlamı Güncel Türkçe Sözlük'te yoktur. Bu anlam kıran gir- birleşik yapısının altına alınmıştır. Sözlükte kıran girmek "1. Kısa bir zaman içinde çok sayıda ölmek. 2. Bir şey bulunmaz olmak" şeklindedir. Kıran kelimesinin salgın anlamını içerdiğinin farkında olarak ya da olmayarak günümüzde de önce birleşik yapıda kalıplaştığı açıktır. "kıran girmek" ifadesindeki bir şey bulunmaz olmak anlamı neredeyse tüm bu birleşiklerin kapsayıcı anlamı olarak düşünülebilir.

\section{Ölet}

Yukarıda kıran sözcüğünün anlamında ölet kelimesinin kullanıldığı belirtilmişti. Ölet kelimesi 1945'ten itibaren Türkçe sözlüklerde yer almıştır. Aynı zamanda Tarama Sözlüğü'nde de "salgın hâlindeki ölüm, kırgın, kıran" şeklinde verilerek kıran kelimesi ile eş tutulmuştur. Tarama Sözlüğü'nde 14. yüzyıldan verilen bir örnek, kelimenin kullanımındaki bir ayrıntının fark edilmesini sağlamaktadır. "Hem ölet ola bu yıl ey namdar, Yil yaramazdır yavuzdur rüzigar" beytindeki bu yıl ölet ola ifadesi ölet kelimesinin sadece salgın değil aynı zamanda afet anlamını da ortaya koymaktadır. Nitekim Kâmûs-i Türkî' de ölet kelimesi, “ölmek"ten "salgın insan ve hayvan hastalığı ölet yılı" şeklinde geçmekte ve ölet yılı örneği yüzyıllar sonra da görülebilmektedir.

Türkçe Sözlük'teki ölet kelimesi 1945 ile 1969 arasında yayınlanan sözlüklerde “öldürücü hastalık salgını" şeklindedir. 1998'ten itibaren ise bu tanıma hem kıran sözcügü eklenmiş hem de kelime için esk. kısaltması eklenerek sözcügüun kullanımdan düştüğü gösterilmiştir. Misalli Büyük Türkçe Sözlük'te ise ölet kelimesinin halk ă̆zında kullanıldığı belirtilmiştir. Kelimenin bu anlamı günümüzdeki Güncel Türkçe Sözlük'te de değişmemiştir. Ancak Güncel Türkçe Sözlük'te eskimiş ifadesi kaldırılmış bunun yerine halk ă̆zında ifadesi eklenmiştir. Kelimenin halk ağzında kullanılmış olduğuna dair açıklama halk ağzından derlenen sözcüklerin bulunduğu Derleme Sözlüğü'nü akla getirmektedir. Ölet sözücüğü Derleme Sözlüğü'nde bulunmaktadır ve kullanıldığı coğrafyanın oldukça geniş olduğu görülmektedir. Derleme Sözlüğ̈̈'nde ölet kelimesi; “1. Öldürücü hastalık salgını, kıran. 2. Veba. 3. Kolera. 4. Salgın, bulaşıcı" (2009, s. 3331) şeklinde açıklanmaktadır. Görüldüğü üzere kelimenin birinci anlamı 
Güncel Türkçe Sözlük'teki anlamı ile aynıdır. İkinci ve üçüncü anlamlarında ise kelimenin doğrudan veba ve kolera olarak algılanması, söz konusu hastalıkların toplumdaki salgınının ne kadar kuvvetli ve etkileyici olduğunu göstermektedir.

\section{Epidemi}

Buraya kadar verilen kelimeler ve anlamları içerisinde geçmese de salgın kelimesine karşılık olarak kullanılan ve müstevli sözcügünün tersine Batı kökenli bir sözcük olan epidemi kelimesini ele almak gerekmektedir.

Epidemi kelimesi ilk olarak 1974 yılındaki Türkçe Sözlük'te ortaya çımaktadır. "Salgın hastalık" şeklinde verilen kelimenin bu anlamı sonraki sözlüklerde de devam etmiştir. Günümüzdeki Güncel Türkçe Sözlük'te ise epidemi kelimesi sadece salgın kelimesi ile açılanmıştır.

Türkçede Batı Kökenli Kelimeler Sözlüğü'nde epidemi kelimesi Salgın hastalık anlamı ile verilmiştir.

Peyami Safa 1947 yılında Vakit Gazetesi'ndeki köşesinde Bir okuyucuya cevap başlığ ile bir yazı kaleme almıştır. Bu yazıda bir okurun kendisini Fransızca kelimeler kullanması konusundaki eleştirilermesine cevap vermiştir. Okurun Fransızcasını kullandığı için yazarı eleştirdiği kelimelerden biri de epidemidir. Peyami Safa bu soruya şu cevabı vermektedir:

Epidemi kelimesinin terim olarak Türkçesi (salgın) değildir. Şemsettin Saminin (salgin köpek) misalinde olduğu gibi bu kelime bizde hastalık salgınlarından başka halleri ifade için sıfat yerinde kullanılır. Bunları ayırmak için (hastalık salgını) gibi bir terkip yapmak da elvermez. Çünkü hastalık salgınları iki türlüdür: Bir kısmı arizi öteki de devaml sebeplerden ileri gelir. Birine epidemi, ötekine de andemi (endemie) derler. Ben "cinayetlerin çoğalması" başlıklı ve okuyucunun tenkidine esas olarak aldığı yazımda, cinayetlerin harp ve buhran gibi arizi sebeplerin neticesi olabileceği faraziyesinden bahsederken (epidemi) kelimesini kullandım. (Salgin) bu özelliği ifade etmez. Fakat yazının diğer taraflarında dört tane (salgın) kelimesi vardır. Çünkü o cümlelerde, arizi sebeplerden ileri gelen epidemiler değil, umumi manasiyle cinayet salginları bahis mevzu idi.

$\mathrm{Bu}$ açılama sadece epidemi kelimesinin değil salgın kelimesinin anlamı ve kullanımındaki detayı da göstermektedir. Peyami Safa'ya göre epidemi kelimesi ile salgin kelimesi arasındaki en temel fark arizi olup olmamaları ile ilgilidir. Arizi kelimesi Güncel Türkçe Sözlük'te "Sonradan olan, dıştan gelen" ve "geçici, eğreti" anlamları ile verilmiştir. Peyami Safa epidemiyi arizi olarak görmektedir. Bu duruma da savaşı ve savaşta olan ölümleri örnek olarak vermektedir. Günümüzde ise bu durumun tersi söz konusudur. Bir savaşın yayılma alanı ya da bir savaş sebebiyle gerçekleşen ölümler salgın olarak nitelendirilmemektedir. 


\section{Pandemi}

Epidemi kelimesi ile çağrışım yapan ve günümüzdeki Covid-19 virüsünün yaygınlığını ifade ederken kullanılan pandemi kelimesi ise Türk Dil Kurumu'nun yayınladığ 1 hiçbir sözlükte yer almamaktadır. Epidemi kelimesinin kullanıldığı bir sözlükte pandeminin olmaması dikkat çekicidir. Pandemi epideminin anlamını kapsayan bir kelimedir. Üstelik pandemi kelimesinin anlaminda yerel olmayan ve pan ön eki sebebiyle tüm halkı içine alan bir anlam vardır. Covid19 salgının ardından yazılan makale ve yayınlarda pandemi kelimesinin salgın karşılığında verildiği görülmektedir. Türkiye Cumhuriyeti Sağlık Bakanlığı resmî internet sitesinde Covid19 Bilgilendirme Sayfası bulunmaktadır. Bu sayfada COVID-19 Sözlüğü de yer almaktadır. Bu sözlüğe, https://covid19.saglik.gov.tr/TR-66493/p.html adresinden ulaşılabilmektedir. 2020 yılının Mart ayından itibaren tüm dünyayı etkisi altına alan virüs için doğru bilgi kaynağı olması bakımından sözlük 24 Kasım 2020 tarihinde erişime açılmıştır.

Alfabetik olarak verilen sözlükte pandemi kelimesi vardır. Söz konusu sayfada pandemi kelimesinin açıklaması: "Bir hastalığın veya enfeksiyon etkeninin ülkelerde, kıtalarda, hatta tüm dünya gibi çok geniş bir alanda yayılım göstermesi. Açıklama: COVID-19, ülkemizde de ilk vakanın görüldüğü 11 Mart 2020 tarihinde Dünya Sağlı Örgütü (DSÖ) tarafından pandemi ilan edilmiştir." Şeklindedir. Burada verilen anlamda da pandeminin kapsayıcılığına dikkat çekilmiştir. Türkçe Sözlük'te uzun yıllar varlığını sürdürmüş epidemi kelimesine ise Sağlık Bakanlığının sözlüğünde yer verilmemiştir. Sözlükte epidemi kelimesi ancak salgın kelimesinin açıklamasında görülmektedir. Epidemi ve pandemi arasındaki tıbbî ayrım salgın kelimesinin anlamı verildikten sonra yapılan açıklama ile açıklığa kavuşturulmuştur: Epidemi, bir topluluk veya bölgede görülen salgındır. Pandemi ise birçok ülkede, küresel düzeyde yaygın olarak görülen salgındır."

\section{Salgın Kavram Alanındaki Diğer Kelimeler}

Tüm dünyanın hâl-i hazırda bir salgın altında olduğu düşünüldüğünde, zihinlerde salgın kavramının çağrışım alanının oldukça güncel ve taze olduğu söylenebilir. Yalnız güncel olan bu çağrışım alanı Covid-19 bağlamındaki salgına aittir. Bu iki bağlamın Covid-19 ve salgın kelimelerinin kesiştiği noktada hem sözlüklerde yer alan kullanım sıklığ1 yoğun olmayan kelimeler hem de insanların hayatına yeni giren sözcüklerden, kelime gruplarından söz etmek mümkündür. Salgın kavram alanında kullanılan kelimelerin bir kısmı ise Covid-19'dan bağımsız olarak herhangi bir bulaşıcı hastalık için kullanılabilecek kelime ve kavramları içermektedir. Temizlik, bulaşma, hasta, vaka, asemptomatik, bağışıklık, entübe, antikor, aşı, ateş, öksürük, damlacık gibi kelimeler Covid-19'dan bağımsız olarak da kullanılan terimler ve kavramlardir.

Burada ise sözlüklerdeki salgının kavram alanı konu edilmektedir. Covid-19'un herkesin gündelik yaşamında ve hayatında yaptığı geçici ve kalıcı değişiklikler göz önüne alındığında sözlüklerin de şimdi olmasa bile bu toplumsal etkiden muaf kalması mümkün gözükmemektedir.

Türkçe Sözlük'lerde madde başında değil, madde açıklamasında kullanılan ve salgın kelimesini içeren yirmi kelime bulunmaktadır. Bir sözcükte ise salgın kelimesi sözlük anlamında değil bir kelimeye örnek olarak verilen cümlede geçmektedir. Bu sözcük tvist 
kelimesidir. Tvist kelimesinin 1983 yılındaki anlamında; 1961 yılında yaygınlık kazanan hareketli bir dans türü olduğu belirtildikten sonra Aziz Nesin'den bir örnek verilmiştir: "Bu çarliston, şimdinin tvist gibi salgınlarına benzemez, çok daha korkunç bir şey". Bu örnek daha önce salgın kavramı incelenirken de belirtildiği gibi Cumhuriyetin ilk yıllarından itibaren kullanılan salgin kelimesinin dile ne kadar yerleştiği ve yan anlamlar kazanarak bir dans türünü dahi ifade edecek duruma geldiğini göstermektedir.

Sözlüklerde salgın kavram alanında bulunan kelimelerin önemli bir kısmını elbette hastalık adları oluşturmaktadır. Boğmaca, çiçek, dang, enflüanza, grip, kabakulak, kolera, suçiçeği maddeleri, anlamında salğn kelimesinin kullanıldığı hastalık isimleridir. Söz konusu hastalıkların anlamlarında salgın kelimesinin kullanılması, ortaya çıtıkları dönemde ve yerlerde yıkıcı etkilerini de göstermektedir. Modern tıbbın ilerlemesi birçok hastalığın sayıca fazla olarak görülse de salgın olma riskini ortadan kaldırmaktadır. Toplumsal olayların sözlüklerdeki yansıması bu kelimeler üzerinden de takip edilebilmektedir. Örneğin, boğmaca ve enflüanza kelimelerinin anlamlarında kullanılan salgın kelimesi 1983'ten itibaren kaldırılmıştır. Bunun aksine suçiçeği maddesinin açıklamasında ise salgın kelimesi 1988'den sonra eklenmiştir. Günümüzde de Güncel Türkçe Sözlük'te suçiçeği; “genellikle çocuklarda görülen döküntülü, bulaşıc1, salgın hastalık" şeklindedir. Türkçe Sözlük'te hem çiçek hem de suçiçeği olmak üzere iki ayrı madde başı bulunmaktadır. Her iki kelime de yukarıda, Türkçe Sözlük'te de bahsi geçtiği gibi salgın kavram alanı içerisindedir. Suçiçeği maddesi Türkçe Sözlük'e 1955 yılında girmiştir. Bu yıldan itibaren yayınlanan tüm sözlüklerde hastalığın çocuk hastalığı olduğu ve/veya çocuklarda görüldü̈̆̈̈ belirtilmiştir. Oysa çiçek maddesinde böyle bir ekleme ya da hastalığın çocuklarda görüldügüne dair bir bilgi yer almamaktadır. Türkçe Sözlük'te "çiçek" maddesi ise 1945 yılında basılan ilk sözlükten itibaren bulunmaktadır. "Çiçek" kelimesinin beşinci anlamı ise; "irinli kabarcıklar dökerek yüzde çirkinleştirici izler bırakan ateşli, ağır, bulaşıcı ve salgın hastalık" şeklindedir. Çiçek hastalığı erken Cumhuriyet döneminde Mardin, Urfa ve Gaziantep'te salgın hâlini almış ve özellikle çocuklarda görülmüştür. Elbette bu salgın çiçek hastalığının ilk kez ortaya çıkması değildir. Burada özellikle bu şehirlerin zikredilmesinin sebebi çiçek aşının 1925'te üretilerek uygulanması ve sonrasında salgının önünün alındığını (Tekir, 2019, s. 422) vurgulamak içindir. Aşı ile kontrol altına alınan çiçek hastalığının ağır ve tahrip edici etkisinin gitmesi kelimenin açıklamasındaki irinli kabarcık, iz bırakan, ağır gibi kelimeleri de kaldırarak suçiçeğine dönüşmesine sebep olmuştur. Türkçe Sözlük'te bulunan salgın çağrışım alanındaki, dang, grip, kabakulak, kolera kelimelerinin anlamındaki salgın kelimesi ise dünden bugüne varlığını sürdürmektedir.

Türkçe Sözlük'teki salgın çağrışım alanında kullanılan ve yukarıda değerlendirilmeyen bir sözcük ise kırlağan kelimesidir. Kırlă̆an kelimesi 1945 yılından itibaren "1. Salgın ve ölümlü hastalık. 2. Veba" anlamı ile verilmiştir. Sözcüğün birinci anlamı bir genel isim gibi dursa da ikinci anlamında kelimenin hangi hastalığı işaret ettiği açıkça görülmektedir. Oysa tarihsel metinlerde geçen kırlağan kelimesi günümüzde dolama olarak bilinen ve genellikle parmaklarda görülen bir rahatsızlık anlamında kullanılmıştır. Kelimenin Tarama Sözlüğü'nde kırlağan dışında kurlagan, kurluğan, kurluğaz, kurlağun ve kulgan biçimleri de bulunmaktadır. Kelime anlamı olarak ise; "Etyaran, dolama” açıklaması verilmiştir. Kırlağan kelimesin farklı fonetik değişimleri olan kullanımları aynı madde altında verilmiş olsa da Türkçe Sözlük açısından bakıldığında kırlağan ve kurlağan kelimesi arasındaki sesin fonemik olduğu ve anlam ayırt edici özelliğe sahip olduğu görülmektedir. Türkçe Sözlüğün ilk baskısından itibaren kırlağan ile birlikte kurlă̆an kelimesi de verilmiştir. Kurlă̆an kelimesinin anlamı ise tıpkı 
Tarama Sözlüğü'nde olduğu gibi "etyaran" olarak verilmiştir. Güncel Türkçe Sözlük'e gelindiğinde ise kırlağan sözcüğü madde başı olarak yer almamaktadır. Söz konusu sözlükte yalnızca kurlağan kelimesi bulunmaktadır ve kelimenin anlamı "etyaran"dır. Dolayısıyla kırlağan kelimesinin veba ve öldürücü salgın hastalık ile olan ilişkisinin günümüz için söz konusu olmadığını söylemek yanlış olmayacaktır.

Türkçe Sözlük'te salgının yayılması ile ilgili olarak ise istila ve istilacı kelimelerinin açıklamalarında salgın kelimesinin kullanıldığı görülmektedir. İstila kelimesinin açıklamasında salgın sözcügünün kullanıldığı tek örnek 1969 yılında yayınlanan Türkçe Sözlük'tür. Üstelik salgın sözcüğü burada kelimenin birinci anlamı olarak verilmiştir. Sözlüğün bu baskısı dışındaki diğer baskılarda salgın kelimesi kullanılmamıştır. Ancak istilacı kelimesi için aynı durum söz konusu değildir. İstilacı kelimesi Türkçe Sözlük'e 1959 yılındaki üçüncü baskısında girmiştir. Buradaki ve sonraki birkaç baskıda daha devam edecek olan anlamı; "Bir yere salgın yapan, saldırıcı (ordu)" şeklindedir. Bu anlam 1966, 1969 ve 1974 yılındaki altıncı baskıya kadar kullanılmıştır. Sonrasında ise hem istila hem de istilacı kelimelerinin anlamında salgın sözcügüü görülmemektedir.

Salgın kelimesinin yer arayışında saldırmak fiili ile ilişki kurduğunu gösteren tek örnek istila ya da istilacı değildir. Mukavemetçi kelimesinin anlamında da bu ilişki açıkça görülmektedir. Mukavemetçi kelimesi Türkçe Sözlük'ün 1959 yılında basılan üçüncü baskısından itibaren izlenebilmektedir. Hem bu baskısında hem de 1966 yılında yayınlanan Türkçe Sözlük'te söz konusu kelime; "Düşman salgınına boyun eğmeyip her çeşit araçla karşı gelen yurtsever" şeklinde açıklanmıştır. Sonraki baskılarda ise yukarıda verilen cümle birebir korunmuş ve sadece salgın kelimesi yerini saldırı kelimesine bırakmıştır. Bugün de mukavemetçi kelimesi aynı cümle ile açıklanmaktadır.

"Salgın" kavram alanı ile ilgili diğer iki kelime ise sivil toplum örgütü ismidir. "Kızılay" ve "Kızılhaç" kelimeleri günümüzde kullanılan Güncel Türkçe Sözlük'te yer almamaktadır. Ancak kızılay kelimesi, 1959'dan 1983 yılına kadar sözlüklerde bulunmaktadır. Kelimenin anlamı; "Yurt içinde ve dışında savaş, deprem, hastalık salgını, yangın ve su baskını gibi durumlardan zarar görenlere ilâç, yiyecek, giyecek, çadır sağlayan ve bağışlarla yaşayan bir kurum" şeklindedir.

Kızılhaç kelimesi ise 1959, 1966, 1966 ve 1974 yıllarında yayınlanan sözlüklerde görülse de sözcüğün açılamalarında salgın kelimesi yer almamaktadır. Yalnızca kelimenin 1983 yılındaki anlamında; "Savaş, deprem, salgın hastalık vb. durumlarda zarar görenlere yardım eden uluslararası örgüt" açıklaması yapılmıştır. Burada kızılay kelimesindeki hastalık salgını ifadesinin salgın hastalık hâlini almış olması da dikkat çekicidir.

\section{Sonuç}

“İkinci Dünya Savaşından sonra, haberleşmenin ve bilgi akışının önem kazanması bazı disiplinlerin veya iş kollarının gelişmesine sebep olmuştur. Bu dallardan biri de sözlükçülüktür" (Usta, 2010, s. 94). 20. yüzyılda modern anlamda oluşturulan genel sözlüklerde geçen madde başlarını inceleyerek toplumun değişim ve dönüşümlerini izlemek mümkündür. Hazırlanan sözlüklerin bir dilde kullanılan bir kelimeye yer vermemeleri mümkündür. Ancak bir dilde olmayan bir kelimenin sözlükte kendine yer bulması bu ihtimale 
göre daha güçtür. Genel sözlüklerde, o dilin sık kullanılmayan, eskimiş, halk ağzından alınmış kelimeleri bulunabilir. Ne sıklıkla kullanılırsa kullanılsın bir dilin sözlüğündeki kelimeler o dilin sözlügüünde yer aldıysa vardırlar. Üstelik sözlükteki hiçbir kelime tek başına değildir. Sözlükte madde başı olan sözcüklerin, "birbirleriyle ilişkili ve birbirine yakın kavramların, eşanlamlıların içinde" (Aksan, 1971, s. 254) düşünülmesi kavram alanını da tanımlamak demektir.

Bir tek kelime ile başlayan kavram ve çağrışım alanı bir zincirin halkalarının birbirine eklenmesi gibi çoğalmaktadır. Bu çalışmada da salgın kelimesinin kavram alanı Türkçe sözlükler üzerinden ele alınmıştır. Cumhuriyet ile birlikte dilde Öztürkçeleşmenin neden olduğu pek çok dilbilgisi tartışması ortaya çıkmıştır. Burada yapılan ise salgın sözcüğü üzerinde adeta mikroskobik bir inceleme ile bu durumun izlerini sürmektir. Türkçenin en eski köklerinden birinin tarih boyunca geçirdiği fonetik ve semantik başkalaşma kendiliğinden değil, belirli toplumsal olaylar sonucu olmuştur. Şimdi düşünüldügünnde salgin ve vergi kelimelerini aynı kümeye koymak mümkün değildir. Oysa salgın kelimesinin seyrinde bu izi takip etmek mümkündür.

Salgın kavram alanındaki, müstevli, ölet, kıran gibi diğer sözcükler de dilin değişebilir olma özelliği ile zaman zaman kullanım sıklığını arttırarak zaman zamansa yalnızca dildeki varlıklarını korumaya çalışarak Türkçenin söz varlığında yer almışlardır. Bu çalışmada tamamlanmış ve basılmış sözlüklere bugünden bakılırken aynı zamanda içinde bulunduğunuz salgın dönemi, geleceğin sözlüklerindeki değişimin de habercisidir. Örneğin Türkçe sözlüklerde tifo salgını örneğinin Covid-19 salgımı olarak değiştirilmesi artık kimseyi şaşırtmayan hâl-i hazırda tanık olunan bir sürecin sonucu olacaktır.

Bir salgının ortasındaki toplumdaki çağrışım alanları ile sözlüklerdeki salgın çağrışım alanlarının son derece farklı olması ise günümüzdeki haberleşme teknolojilerinin, internetin ve sosyal medyanın hızı ile ilgilidir. Sokaktaki insanlara "salgın dendiğinde aklınıza gelen 10 sözcüğü sıralayınız" şeklinde cümle yöneltilse Türkçe sözlükteki çağrışım alanına giren kelimelerin hiçbirinin sayılmaması mümkündür. $\mathrm{Bu}$ durum son derece olağandır. Günümüzde salgınla ilgili bilgilendirme ve haber alma kaynakları radyo ve basılı gazete ile sınırlı değildir. Trafik lambalarındaki "evde kal" yazıları, çeşitli işletmelerde ve kurumlardaki sosyal mesafe işaretleyici etiketler, binaların girişindeki uyaranlar ve dezenfentanlar, telefon uygulamaları ile kişinin ve bulunduğu konumun riskli olup olmadığı ve/veya ne kadar riskli olduğuna dair görüntüler sözlüklerdeki salgının kavram/çağrışım alanının uzak, donmuş ve kalıplaşmış bir hâl almasını sağlamaktadır.

Yaşanan Covid-19 salgını başta Sağlık Bakanlığı olmak üzere çeşitli haber siteleri, sosyal medya uygulamaları ve blogların hazırladığı çok sayıda salgın sözlügüunü de ortaya çıkarmıştır. Tüm bu sözlüklerin ayrı bir çalışma konusu olarak ele alınması mümkündür.

Ayrıca salgın gibi doğrudan bir yeri ve coğrafyayı etkisi altına alan kavramların ve çağrışım alanlarının Derleme Sözlüğü gibi yer ve konumdan hareketle hazırlanmış sözlüklerde takibi de oldukça dikkat çekici olacaktır. Bir başka çalışma konusu olarak toplumsal olayların Derleme Sözlüğ̈̈'nde kullanıldıkları yerleri eşleştirmek olabilir. Veba ve koleranın ölet kelimesinin örneği olarak verilen yerler -örneğin veba için Manisa, Malatya, Antakya ve Adana Kolera sözcüğü için ise Isparta ve Malatya'nın verilmesi- diğer şehirlerde bu kelimenin bu anlamlarının olmaması veba ve kolera salgınının söz konusu coğrafyalardaki yoğunluğunu mu göstermektedir? 
İster burada ele alındığı gibi salgın kavramı olsun ister başka kavramlar konu edilsin, herhangi bir sözcügün toplumsal olayların izinde ve o olaylara paralel olarak sözlüklerden takip edilmesi o toplumun söz varlığının anlaşılabilmesine 1şık tutmaktadır.

\section{Kaynakça}

Aksan, Doğan, (1971). “Kelimebilimi ve Anlambilimi Ölçülerinden Yararlanarak Bir Yazı Dilinin Eskiliğini Saptama Yolları I: Kavram Alanı-Kelime Ailesi İlişkileri ve Türk Yazı Dilinin Eskiliği Üzerine" Türk Dili Araştırmaları Yıllı̆̆g-Belleten, 19, s. 253-262.

Aksan, Doğan, (2006). Anlambilim- Anlambilim Konuları ve Türkçenin Anlambilimi, Ankara: Engin Yayın Evi.

Atalay, Hamit, (1999). İngilizce-Türkçe Sözlük, Ankara: Türk Dil Kurumu Yayınları.

Ayverdi, İlhan, (2016). Misalli Büyük Türkçe Sözlük, İstanbul: Kubbealtı Yayınları.

Bekdaş, Müjgan, (2017). “Sözlük Türlerinin Tasnifi”, Route Educational and Social Science Journal 4/4: s. 52-59.

Bozkurt, Ferdi, (2016). "Genel Sözlükler İçin Sözlük Birim Seçimi Ölçütleri”, Doktora Tezi, Eskişehir Osmangazi Üniversitesi Sosyal Bilimler Enstitüsü.

Çağbayır, Yaşar, (2007). Yazıtlarından Günümüze Türkiye Türkçesinin Söz Varlığı Ötüken Türkçe Sözlük, İstanbul: Ötüken Yayınevi.

Ergin, Muharrem, (2009). Dede Korkut, Ankara: Türk Dil Kurumu Yayınları.

Kıran, Ayşe Eziler - Kıran, Zeynel, (2002). Dilbilime Giriş. Ankara: Seçkin Yayınevi.

Özyetgin Melek, (2007). “Türk Vergi Sisteminde Salı", IV. Türk Dili Kurultayı Bildirileri Ankara: Türk Dil Kurumu Yayınları, s. 1453-1463.

Parıldar, Hülya, (2020). “Tarihte Bulaşıcı Hastalıklar”, Tepecik Ĕ̆it. Ve Araşt. Hast. Dergisi, 30 (Ek sayı): s. 19-26.

Pars, Tuğlacı, (1971). Okyanus Ansiklopedik Sözlük, İstanbul: Pars Yayınları.

Polat, Nazım, Hikmet, (2016). Ömer Seyfettin Bütün Eserleri (Fıkralar, Makaleler, Mektuplar ve Çeviriler), Ankara: Türk Dil Kurumu Yayınları.

Remzi, Hüseyin, (1305). Lugat-ı Remzi, İstanbul: Matbaa-i Hüseyin Remzi.

Sami, Şemseddin, (2005). Kâmûs-i Türkî, Ankara: Türk Dil Kurumu Yayınları.

Tarama Sözlüğ̈̈̈, (1995). 8 cilt. Ankara: Türk Dil Kurumu Yayınları.

Tekir, Süleyman, (2019). “Erken Cumhuriyet Dönemi Türkiye'de Bulaşıcı Hastalıklarla Mücadele (1923-1930)", Atatürk Üniversitesi Türkiyat Araştırmaları Enstitüsü Dergisi, 65., s. 407-430.

Toparlı, Recep, (2000). Lehçe Osmanî, Ankara: Türk Dil Kurumu Yayınları.

Türkçe Sözlük, (1945). Ankara: Türk Dil Kurumu Yayınları. 
Türkçe Sözlük, (1955). Ankara: Türk Dil Kurumu Yayınları.

Türkçe Sözlük, (1959). Ankara: Türk Dil Kurumu Yayınları.

Türkçe Sözlük, (1966). Ankara: Türk Dil Kurumu Yayınları.

Türkçe Sözlük, (1974). Ankara: Türk Dil Kurumu Yayınları.

Türkçe Sözlük, (1983). Ankara: Türk Dil Kurumu Yayınları.

Türkçe Sözlük, (1988). Ankara: Türk Dil Kurumu Yayınları.

Türkçe Sözlük, (1998). Ankara: Türk Dil Kurumu Yayınları.

Türkçe Sözlük, (2005). Ankara: Türk Dil Kurumu Yayınları.

Türkçe Sözlük, (2011). Ankara: Türk Dil Kurumu Yayınları.

Türkçeden Osmanlıcaya Cep Kılavuzu. (1935). İstanbul: Devlet Basımevi.

Türkiye'de Halk Ağzzndan Derleme Sözlüğ̈̈, (2009). Ankara: Türk Dil Kurumu Yayınları.

Usta, Halil İbrahim, (2010). "Sözlükçülük ve Sözlük Araştırmacıllğı", Modern Türklük Araştırmaları Dergisi, 7/2.

Yücel, Hüseyin, (2017). Türkiye Ekonomisinin Kuruluşu ve Gelişimi, Ankara: Türkiye Barolar Birliği Yayınları.

https://bilimgenc.tubitak.gov.tr/salgin-hastaliklarin-tarihi

https://covid19.saglik.gov.tr/TR-66507/s.html

https://www.gastearsivi.com/

https://sozluk.gov.tr/ 


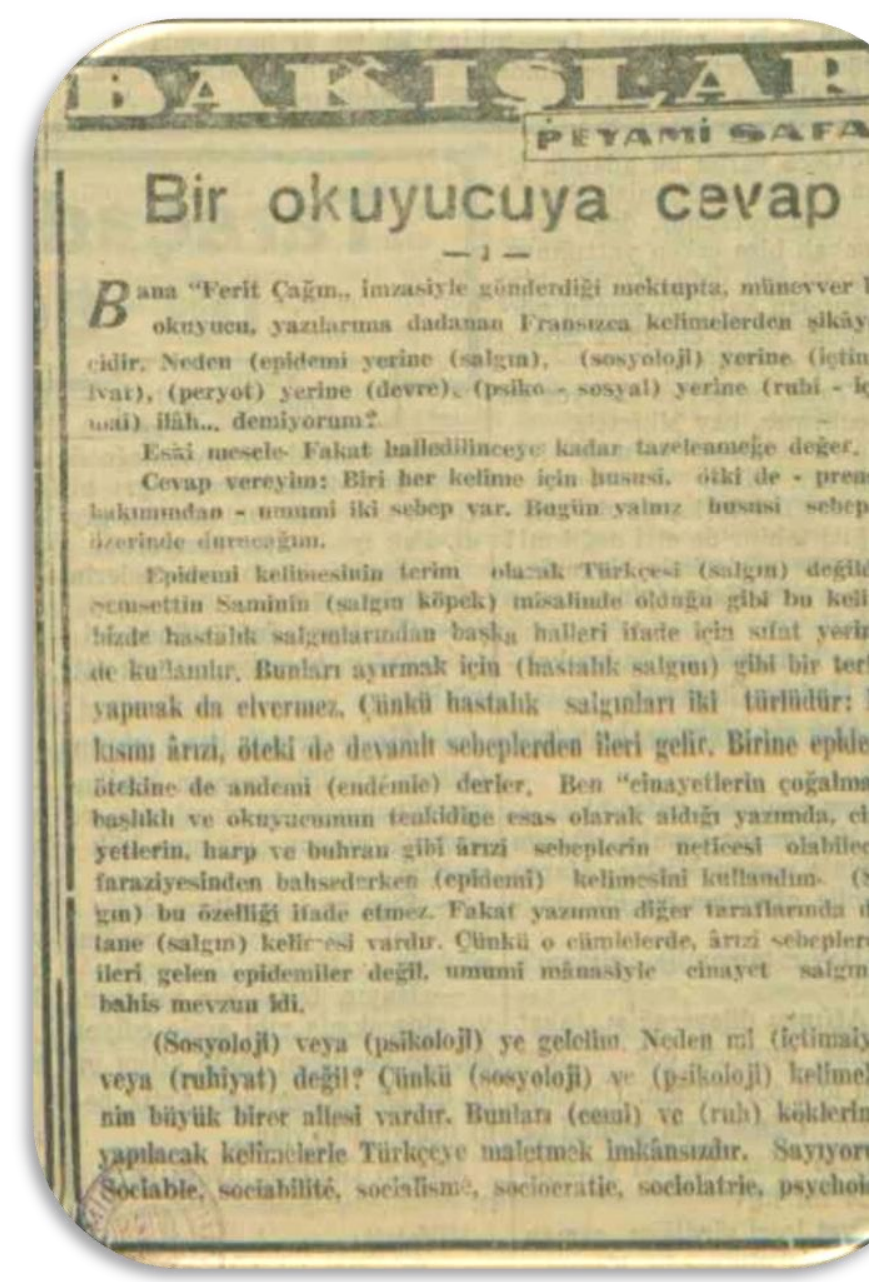

Vakit Gazetesi (11.06.1947)

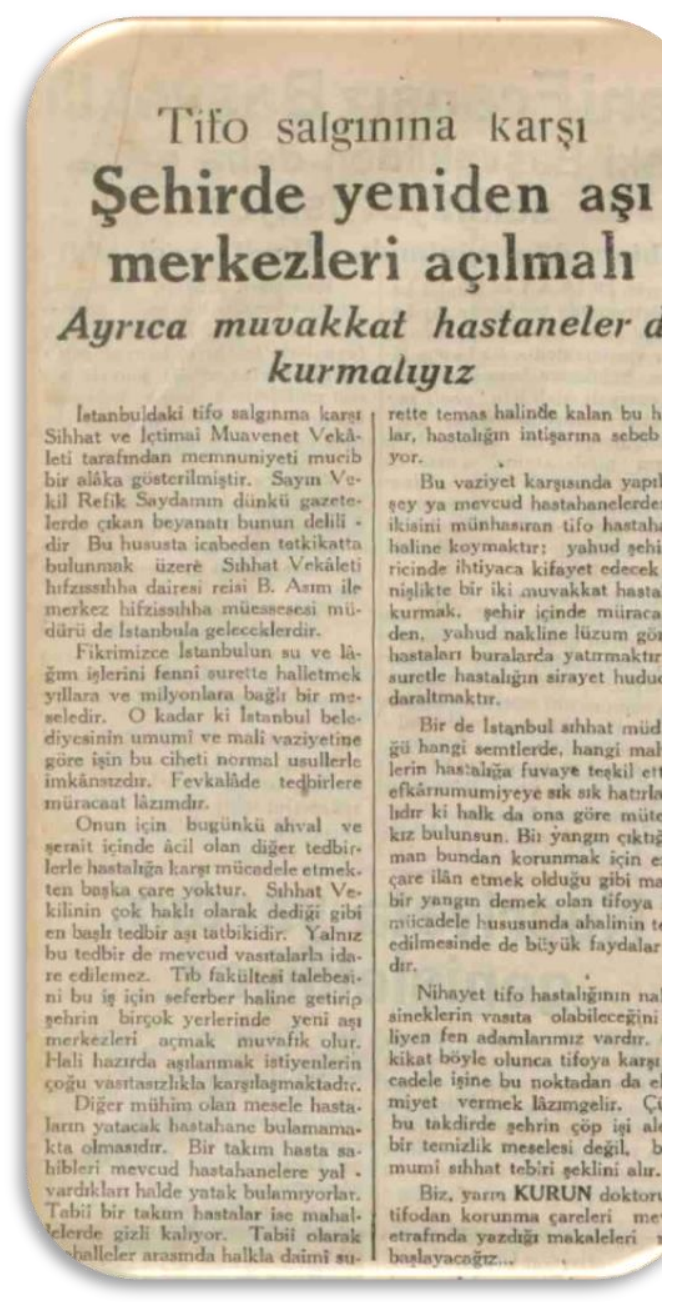

Kurun Gazetesi (30.06.1937) 


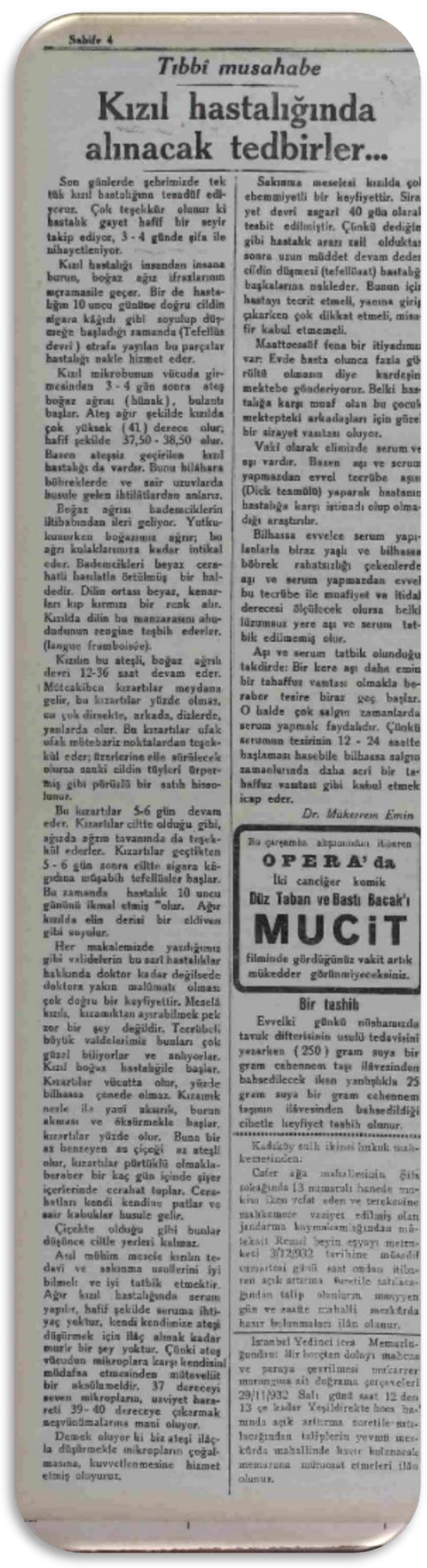

Akşam Gazetesi (28.11.1932)

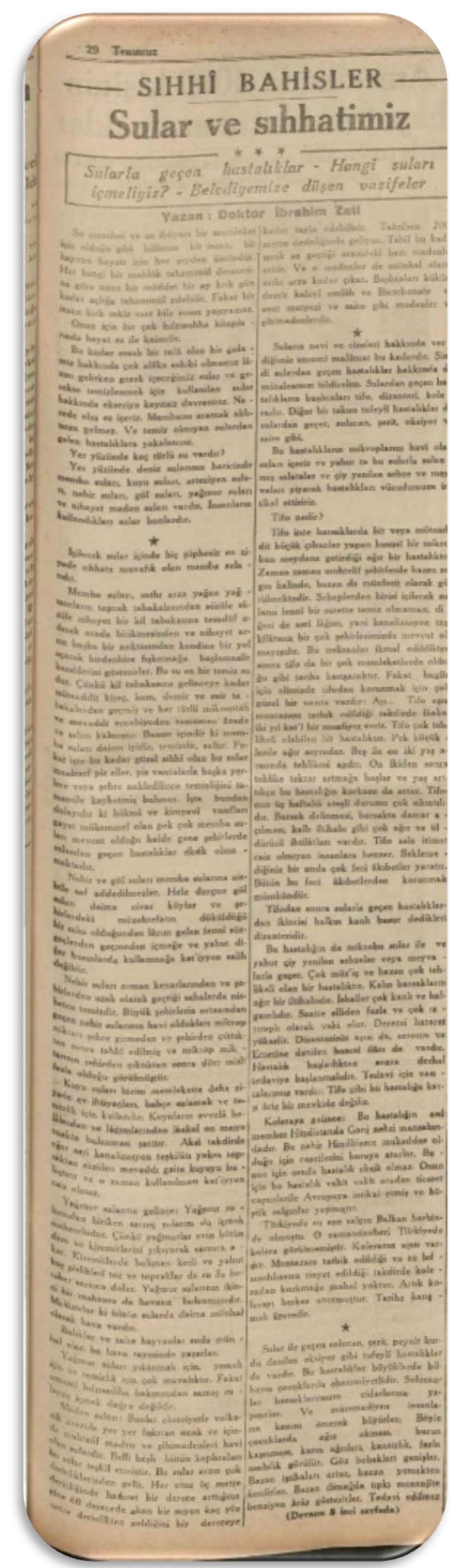

Son Posta Gazetesi (29.07.1936) 


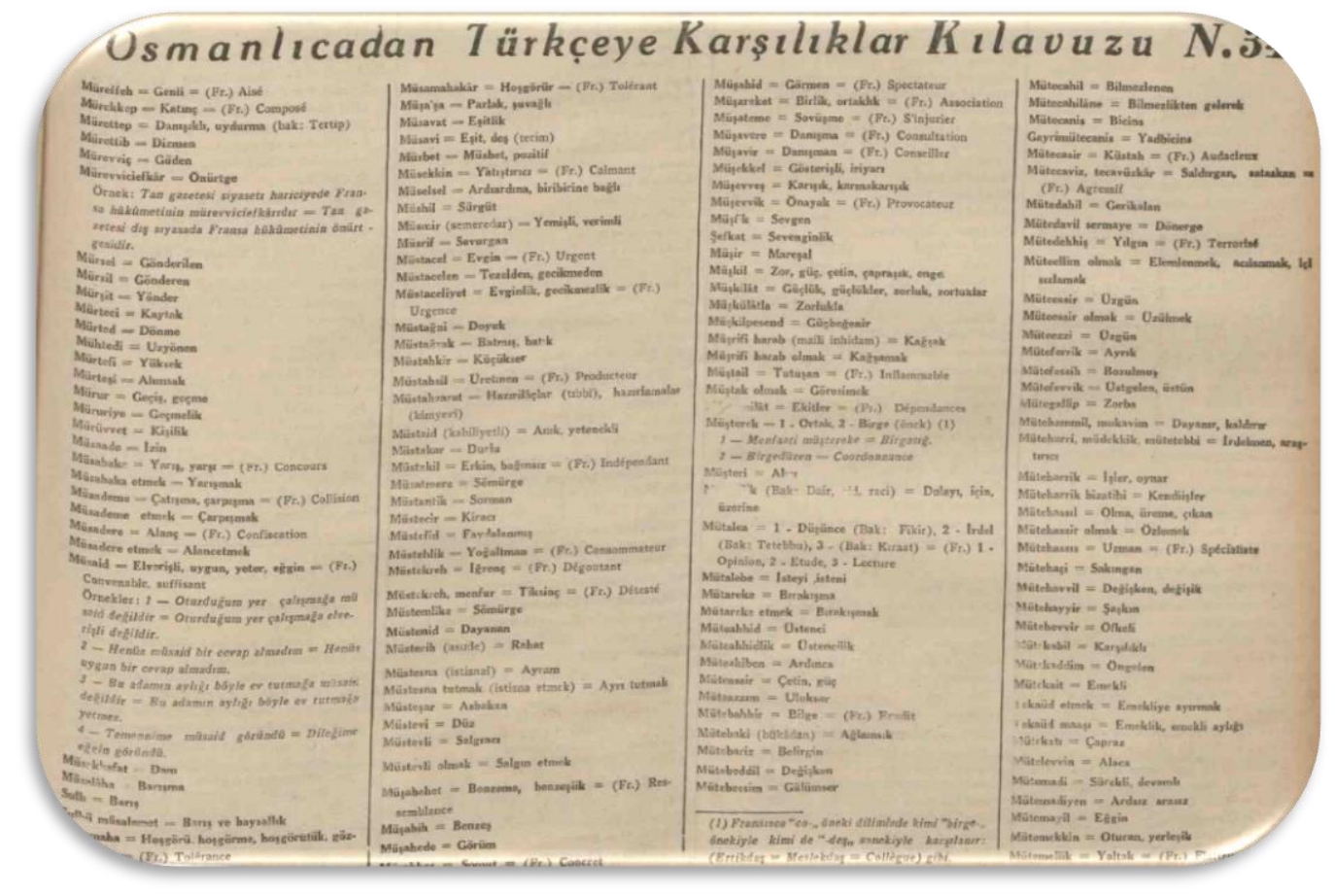

Ulus Gazetesi (27.04.1935)

\section{Açıklamalar}

- Çalışma kapsamında sunulan gazete sayfalarının tamamı https://www.gastearsivi.com/ sitesinden alınmıştır. 